\title{
Enterprise Performance and Assessment Policy in Albania, Needs Social Development Strategies as an Important Key
}

\author{
Prof. Assoc. Dr. Alba Dumi \\ Dean of graduated School "Ismail Qemali" Vlora University, Albania \\ Economy Faculty, Management Department,"Ismail Qemali" University, Vlora Albania \\ Economy Faculty, Management Department, Tirana University, Albania \\ Email:alba.besi12@gmail.com \\ Ma. Emine Emurllai \\ PhD Candidate SEEU University, Public Administration Faculty, Macedonia \\ Email: ee12266@seeu.edu.mk
}

\section{Doi:10.5901/mjss.2013.v4n9p13}

\section{Abstract}

This paper research overview of the leader behavior literature highlighted the fact that there are inconsistent relationships between the behaviors that leaders engage in and the effects of these behaviors on member attitudes, behavior, and group effectiveness. Making decisions is fairly simple if no responsibility is attached to those decisions. True leaders always assume the responsibility for their actions, their plans, their programmer and their decisions. Courage and personal honesty, the marks of leadership, will permit nothing else. Albania like the other transitional countries is left behind from the western countries concerning the real understanding of the term "management". Also, management and the entrepreneurship skills are still considered as resources less efficient than the capital in a moment when management and entrepreneurship play a crucial role in business success and performance. The organizations are under pressure to show return on investment for training and development. Although positive trends, problems which management is faced are more challenging than the degree of preparation and performance that they offer, so their qualitative qualification remains the continuous preoccupation as the role of our school is in this direction. In this point of view education in distance can be considered as complementary approach and in some conditions as a worthy replacement of direct education, which still dominates educative systems in Albania. Implementation of efficient financial and economic policies in order to develop a socio-economic strategy, ensures security and stability in the interest of citizens. For this reason that the need for economic reform remains a priority as regional and European integration depends precisely this fact . Since 2006, Albania as a candidate country that aspires to European Union integration has applied and is monitored periodically for development mode of implementation of these policies. As expected, the unfavorable economic situation in the European continent is expected to have a negative impact on the Albanian economy. Either way, the fact that it will continue to have economic growth is good news for the country, especially in the context of a European economy in crisis.

Keywords: Management, Multifactor Leadership, Performance, Human effort, Public sector, Decision-maker, Albanian leadership

\section{Introduction}

The leader must make timely predictive and reactive decisions. By predictive decisions we mean decisions based on future events rather than on present events. Reactive decisions are based on past events and present conditions. The leader must make timely predictive and reactive decisions. The more predictive decisions a leader makes, the better decision-maker he will be for progress and growth. (Madlen S 2011)The more reactive decisions he makes, the better he will be for administration, organization monitoring and evaluation, and staff functions. In general, true leaders make predictive decisions, while followers make reactive decisions. As time goes by, the capacities of the human resources as a whole and more specifically are considered as the main factors for making the organization more competitive. (Stogdill, R.M 2009)

It has been experienced many times from the Albanian practice that between the effective management, its competitiveness and organizational success wich existed "cause-effect" relationship. Increase of organization's competitiveness, improvement of productivity and development of human and management capacities should be indivisible. (Dumi A, JESR 2012, vol2, nr 3) On the other hand are Keynes -inane, to develop the argument that fiscal 
crisis can only be solved by economic growth, which in the period of crisis precisely achieved through maintaining high level of public expenditure, non drastic reduction. (Zaccaro, S.J, Foti, R.J \& Kenny 1991)

\section{Macroeconomic}

instruments
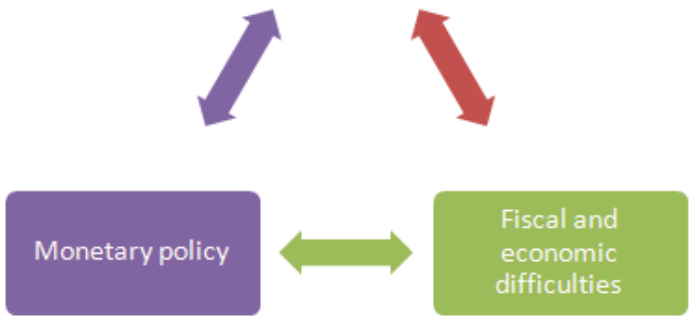

Source: Macroeconomic fundamental instruments: Zaccaro, S.J, Foti, R.J \& Kenny 1991,

In each case, the argument is not about fundamental transformation of the structure of the economy, but to manage the situation through macroeconomic instruments owned by the state: tax policy, public expenditure policy and monetary policy. In short, state policies must be structural, such targeting fundamental transformation of the country's economic composition. (Dumi A, AJIS Vol 2, nr 1, 2013)

However, the rate of economic growth in itself says nothing about the quality of economic development that is happening. Albania is facing significant fiscal and economic difficulties in 2012, while the rate of economic growth in Albania, which remained one of the highest in Europe during the years 2008-2010 financial crisis, is now expected to fall significantly as a result of the effects of shorting measures in Greece and Italy. Budget in Albania have already led to serious spending cuts, with the possibility that these cuts go even deeper, especially the fact that the government can not cover deficits through the sale of public assets, as there is almost nothing left to privatize

The predominating age of business managers varies from 30-39 years old. This fact is the result of a study conducted on the analysis of reforms effectiveness in public management using thus a comparative analysis among public and private sectors. A sample of about 500 questionnaires was used in the above-mentioned study, divided equally in 250 questionnaires to the public administration and 250 ones to private businesses. Our research was conducted in main towns (Tirana and Vlora) of Albania. (Dumi A, AJIS Vol 2, nr 1, 2013)

To complete the research, there was made a multi-phase selection to businesses. In the first phase, towns where the study would be conducted were selected. For this reason, bigger towns in Albania were selected. (See the following table). In the second phase, based on the number of businesses, questionnaires were distributed according the selected towns. (Dumi A, JESR 2012, vol2, nr 3)

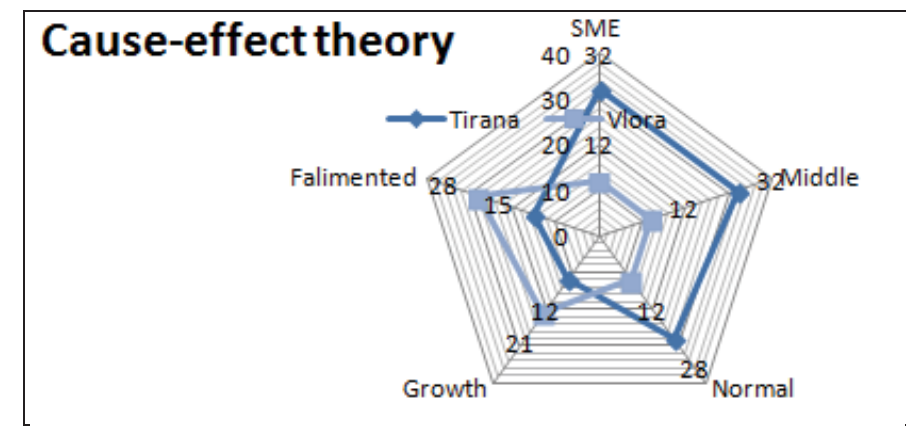

Tab 1: "cause-effect" relationship and effective management, Zaccaro, S.J, Foti, R.J \& Kenny 1991 


\section{Management and Training methodology and content}

Demand driven marketing for the $21^{\text {st }}$ Century introduced participants to marketing mechanisms and environmental considerations for sustainable business development through formal presentations in a classroom setting. (Zaccaro, S.J, Foti, R.J \& Kenny 1991) The presentations were organized as three hour sessions. Participants were provided with notebooks that contained daily overviews and detailed handouts that mirrored the overheads used during the presentations.

Most presentations contained a hands-on component such as a group or individual exercise that was discussed after completion. Presentation topics included: a review of basic marketing concepts, including price, promotion, product and place; experimentation with product/market diversification; effective market analysis - your industry, competition and customer profiles; whether or not export is right for your business; (Schlenker, B.R, 1980)

We visited and spoke to the owners and managers of businesses involving herb farming, flower cultivation, tree and flower nurseries, mushroom germination and packaging, botanical and medicinal oil manufacturers, natural products and health food, open air agricultural and gourmet products, small scale timber processing and others. The Albanians brought diverse expertise to the training including forestry, nursery development, botanical herb collection, wild mushroom gathering plus a wide range of business management skills. (AM report 1999, USAID)

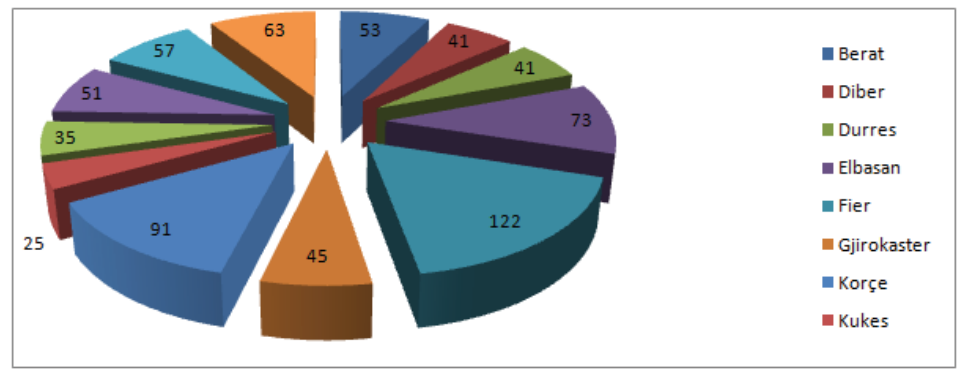

Graph 1. The result of a study conducted on the analysis of reforms effectiveness in public management, (Dumi A, AJIS 2012, vol 1, Nr2)

\subsection{Level of leadership and the management role.}

The levels resonated and reminded me of another theory, Maslow's Hierarchy of Needs, which is used help explain personal motivations and needs in reaching ones full potential. Check out the graphic with this post for each level of Maslow's hierarchy. For PR practitioners, the most basic "need" or skill is to be an effective and strong writer. (Van Fleet, D.D \& Yukl, G.A 1989) Young professionals cannot expect to climb the professional ladder without mastering the technical skills.

The nature of the public sector means that not all of these barriers can be removed. (Schlenker, B.R, 1980) The fact that the public sector is responsible for spending public money means that it has to have a different attitude to risk than the private sector. The work of the public sector cannot, and should not, be detached from political accountability. (Zaccaro, S.J, Foti, R.J \& Kenny 1991)A key part of effective public sector leadership lies in dealing effectively with these constraints. Nonetheless, if leadership in the public sector is to be improved, then attention must be paid to removing environmental barriers as far as possible and to developing an environment that nurtures and rewards leadership. (Dumi A, AJIS 2012, vol1, $\mathrm{nr}$ 2)

These are policies that often preoccupy economists common structural economic policies are fundamentally different from this kind of policy. Of course, in advanced economies and complex, what is e.g. Western Europe or the U.S., the political debate focuses primarily on quantitative policy level. Despite the financial crisis of 2008 urged the need for much deeper state intervention in the economy; however debates revolve around quantitative policy. (Dumi A, AJIS Vol 2, $n r$ 1, 2013)Particular case is the sovereign debt crisis in Europe. On one side are the militants of fiscal discipline, such as finance ministries leaders of countries such as Germany and the Netherlands, which require severe reductions in expenditures, despite the cost and the economic and social consequences. 


\subsubsection{The public sector must create a strong supply of good leaders}

PR pros may be social media savants, but if they can't effectively craft a well-written release or pitch, they can't expect to be invited into senior leadership circles for decision making. Those who have made it to "level 4" leadership in PR have reached Maslow's equivalent of self-actualization, or the best versions of their self because they have mastered the other skills, allowing them to make effective and meaningful contributions. (Stogdill, R.M 2009)

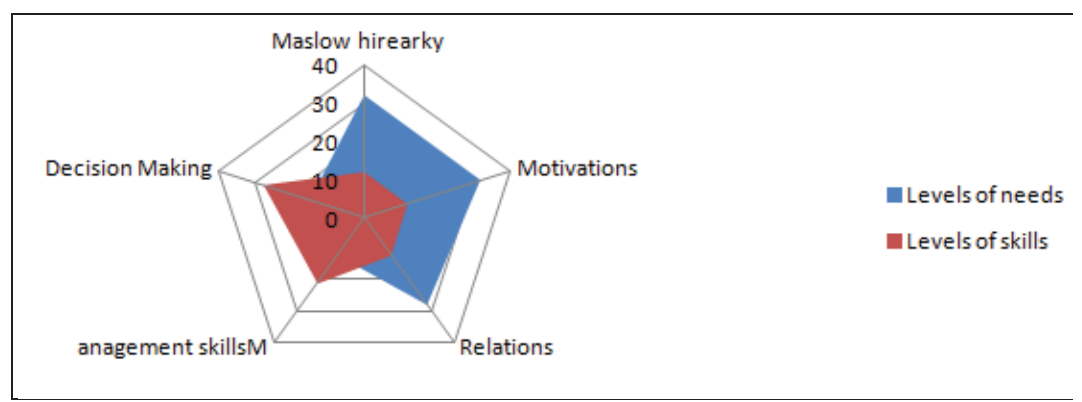

Tab 2: The Maslow Hirearchy of Needs, (Stogdill, R.M 2009)

\subsection{Personal Honesty}

Personal honesty means more than "thou shall not steal." It is a deep dedication to truth: truth to superiors, truth to subordinates, and truth to oneself. To a leader, to a professional, it makes no difference if the truth hurts, heals, destroys, or cultivates, it must be found, stated, and implemented. This is the only atmosphere in which a leader can accomplish and his organization's goal or objectives. 3) Intelligence: - Intelligence and common sense are requisites for leadership. Individuals who lack these qualities occasionally find themselves in position of leadership, and the end is almost inevitable. (Zaccaro, S.J, Foti, R.J \& Kenny 1991)

Blunders, insensitivity, and fearful actions generally lead to failure. (Van Fleet, D.D \& Yukl, G.A 1986) The tragedy is that many innocent people are often hurt in the process.Government needs intelligent, far-seeing creative people at all levels of its organizational structure. These are people who generate new ideas and who are innovative. Their dissatisfaction with routine and commonplace thinking can make a strong push toward change and growth. (Dumi $A$, JESR 2012, vol2, n3)

A good career no longer means a "job for life": the most important guarantees relate not to security but to employability. Any training offered as part of a recruitment package should have some portability or link to a recognised credential, like the new generation of part-time MPA degrees. This could form part of a "development guarantee" to the individual. (Dumi A, JESR 2012, vol2, nr 3)

\section{Literature Review and Hypotheses}

The intelligence that we are looking for in government is more than what an IQ test attempts to measure. It is intelligence plus human understanding, breadth of capability, judgment, reason, imagination, curiosity, and the desire to learn and grow. (Staw, B.M \& Ross, J)

This model has become obsolete. A broader and more diverse group of leaders and future leaders needs to be encouraged to join the public sector, if the sector is to deliver the changes that are being asked of it. The key areas where it should focus its attention are:

- Employability - ensuring that people working in the sector gain skills and experience that will be useful, and are recognised in the wider labour market;

- Conditions of work - ensuring that the public sector maintains its lead in providing good conditions, including good work/life balance and a diverse workforce; (Zaccaro, S.J, Foti, R.J \& Kenny 1991) 


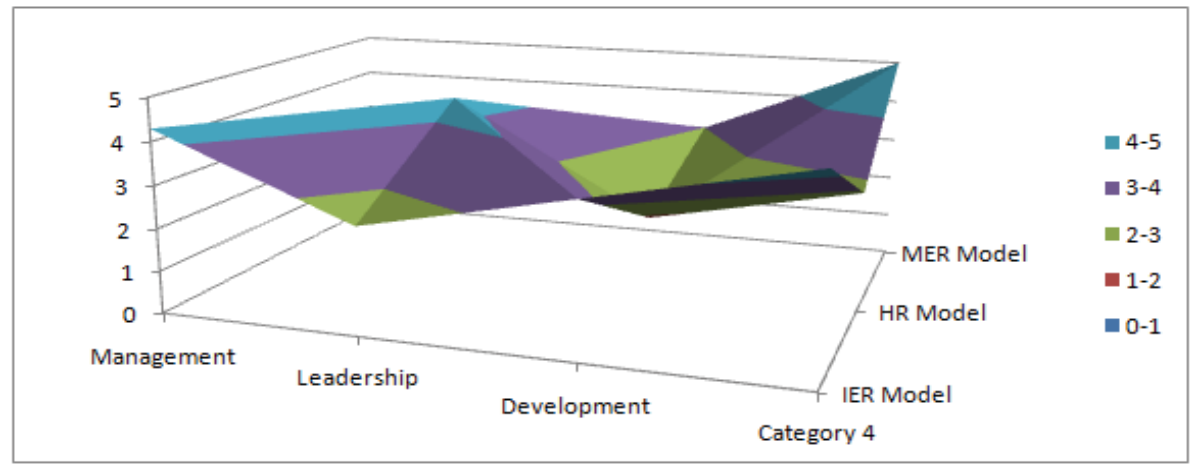

Graph 2: IER model of high quality leadership and human understanding, (Dumi A, AJIS 2012, vol1, nr 2)

Widespread high quality leadership depends critically on recruiting and developing people with the skills to lead. (Zaccaro, S.J, Foti, R.J \& Kenny 1991)Several factors stand in the way. In the first place, the public sector may not be perceived as an attractive career option. In part, this may be a consequence of some of the features of the operational environment described above. Perceptions about pay, conditions of work, progression and the value placed on the work may also contribute. (Dumi A, AJIS 2012, vol1, $n$ r 2)

\subsection{Human Understanding and Personal Beneficial}

Along with intelligence goes the true leader's active concern for others his human understanding. This is a most complex and demanding requirement for leadership. Human concern is attained not only through logic and reason but also through the heart. (Zaccaro, S.J, Foti, R.J \& Kenny 1991)That is, the rights and personal dignity of every man are sacred and cannot be violated or diminished for any purpose no matter how noble or beneficial that purpose, may be. A critical issue in the public sector's attractiveness will be the future career prospects of those entering. (Van Fleet, D.D \& Yukl, G.A 1986)

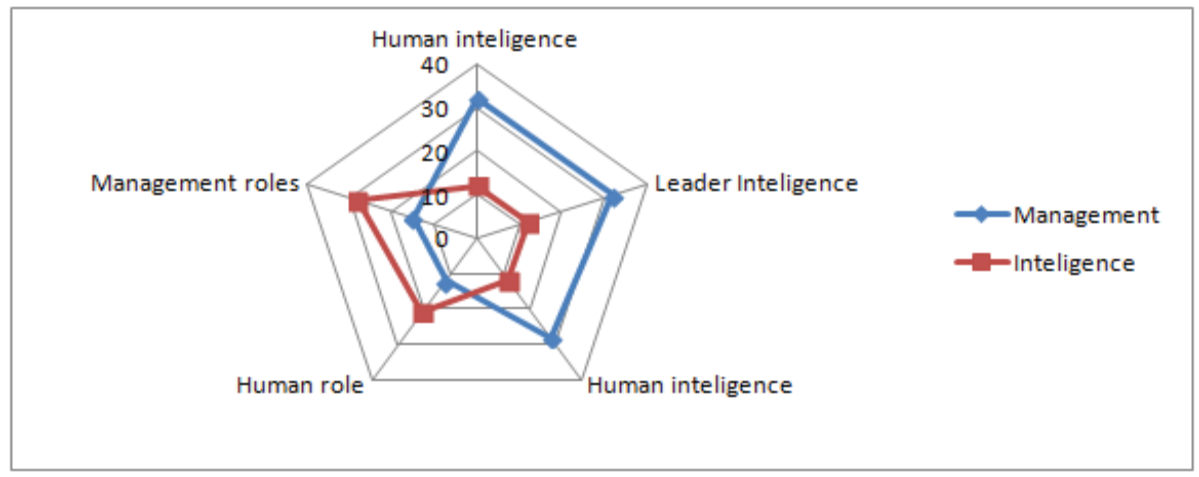

Tab 3: IQ tests and Management of HR, (Staw, B.M \& Ross, J)

The person who would lead must be able to transmit his ideas, convictions, purpose, methods, and approaches to the force that will carry them into action. Further, he must communicate quickly and accurately, so there will be no confusion or delay in the implementation of his planned actions. (Zaccaro, S.J, Foti, R.J \& Kenny 1991)Even more important, a leader must have ability to communicate to his staff the need for their personal dedication to whole organization.

Only by communicating enthusiasm can a leader motivate his people to the level of achievement result in a successful operation. (Andrew Staw, B.M \& Ross, J1980) 


\subsection{The medium term strategic framework}

Taken together, these increased demands on organisations create a need for highly effective leadership and a requirement for new leadership skills. Alongside pressures on leaders to deliver "vertical" services more effectively (public demand for shorter waiting lists and higher school standards, for example), there is a greater demand for "horizontal" leadership within and across sectors. (Zaccaro, S.J, Foti, R.J \& Kenny 1991)Leaders today are less able to manipulate the world through traditional "command and control" methods. They need to collaborate more, manage change through others and focus on customers whose problems may not be susceptible to solution by a single agency. (Quinn, R.E. Spreitzer, 2008 G.M)

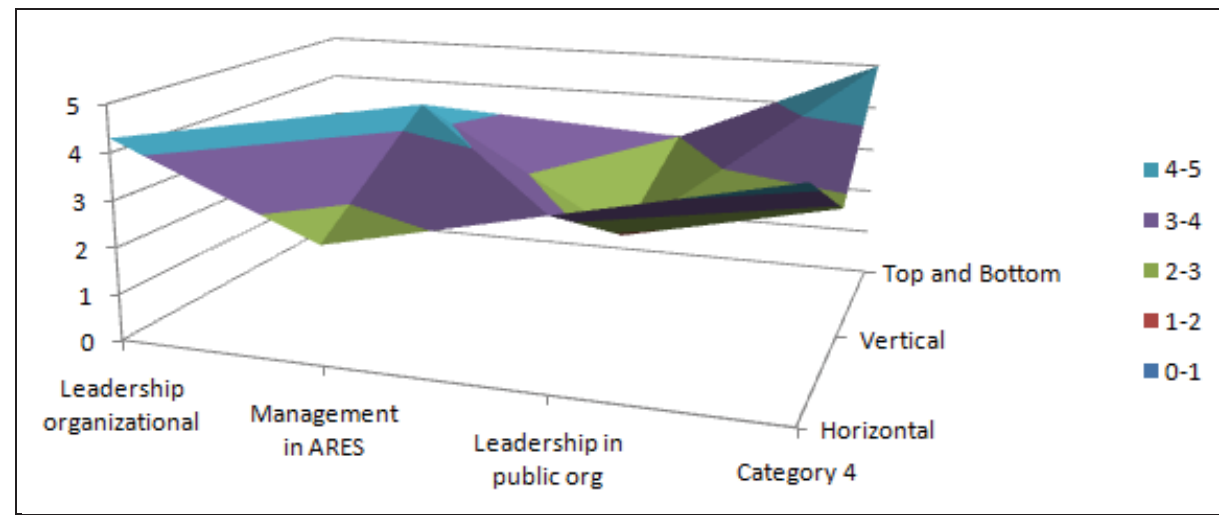

Graph 3: The environment and structures must promote good leadership, (Vroom, V.H \& Yetton references 1973)

\subsection{The essential behaviours and the context of management in organizational leadership.}

Leaders are not always given enough space to lead - almost by definition leadership involves making choices, rather than being solely an agent for decisions made elsewhere. Excessively tight control, and the coexistence of multiple levers of central control, can easily corrode the capacity to lead.Central government in particular should think carefully about how it defines tasks and rewards for leaders in the field. (Van Fleet, D.D \& Yukl, G.A 1986)

These qualities are particularly important in complex areas requiring cross-agency cooperation. Findings from the project case studies and workshops suggest that many public service leaders demonstrate these qualities. However, they often lack a full understanding of why it is that their approach is proving. The environment and structures must promote good leadership. At present, the environment within which public sector leaders operate contains important barriers to good leadership. Some of these are discussed in a wider context in the PIU report Wiring it Up, and the findings of this project's case studies and workshops contribute further to our understanding of them. (Vroom, V.H \& Yetton references 1973)

\subsubsection{Key structural and cultural barriers within the public sector.}

- The public sector has an aversion to risk. Essential leadership behaviours, such as defining and communicating radical goals and achieving them by unconventional means, contain inherent risks. This sort of risk taking tends to be discouraged, and leadership along with it. (Dumi A, AJIS 2012, vol1, nr 2)

- There is a blame culture in the public sector. The public sector tends to be intolerant of failure and can make people working in the sector overly cautious about trying new and different approaches. This reflects fears that the media and parliament are much more likely to penalise failure than to reward success. The attempt to eliminate failure can therefore hamper the development of leadership and prevent the creation of learning organisations. (Staw, B.M \& Ross, J 1998) 


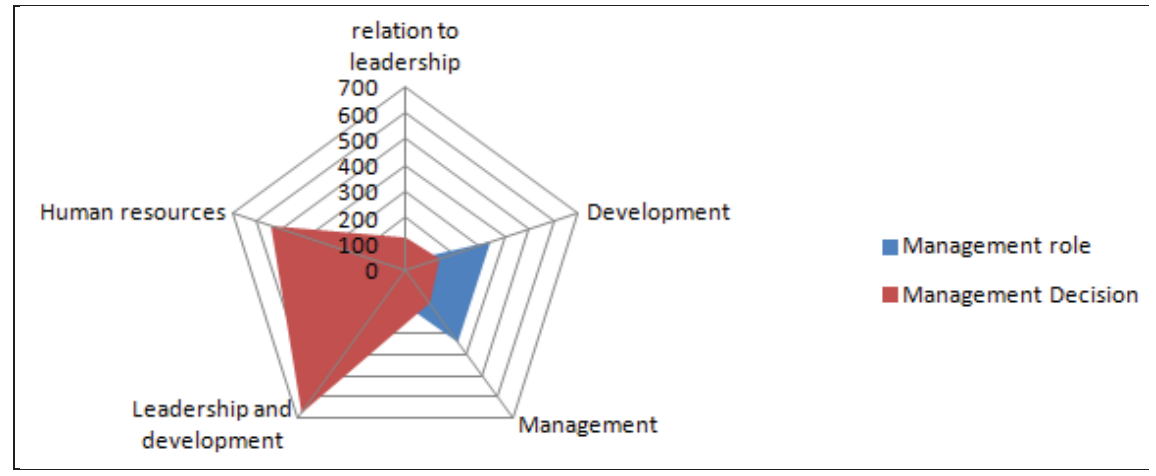

Graph 4: A similar picture emerges in relation to leadership development activities. (Dumi Alba JESR 2012, vol2, nr 3)

Lack of clarity about what makes leaders effective is reflected in lack of clarity about what makes leadership development programmes effective. The two key challenges facing the public sector in creating a strong supply of effective leaders are: • effective recruitment for leadership, whether recruiting people to take on major leadership roles, or at lower levels as future leaders; and - developing leaders effectively, to bring out the potential of those who will take key leadership roles in future. (Quinn, R.E. Spreitzer, 2008 G.M)
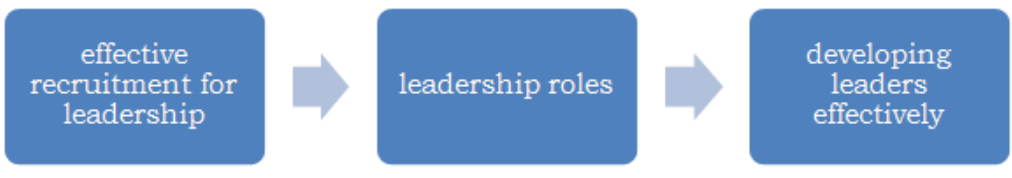

Tab 3: The three key challenges facing the public sector, (Quinn, R.E. Spreitzer, 2008 vol 3 G.M)

\section{Methodology and Research Goal}

The democratic context and the role of politicians is one of the distinguishing characteristics of the public sector. Politicians do not just set the current framework of control within which public services are delivered they are also leaders in their own right. Government ministers are accountable for public service delivery to parliament and to the wider electorate. Local political leaders are accountable to their local electorates. Both local and national leaders have a mandate to deliver the policies in their manifestos. (Van Fleet, D.D \& Yukl, G.A 1986)

\subsection{The Situation on the Institutional Framework}

SME activity in Albania is closely linked with a variety of public institutions such as ministries, agencies, regulatory bodies, as well as the Courts, Institute of Statistics and local government. This is a complexrange of organisations that do not always co-ordinate and co-operate in forging ahead with the agenda for improving the business environment. The principal responsibility for SME policy development falls to three main bodies: the Business Promotion Department of the Ministry of Economy, the Small Business Development Agency (the SBDA is expected to start operating at national and regional level in the near future); and the Economic Policy Committee, reporting to the Council of Ministers and operating at the inter-ministerial level.

\section{Data and methodology of study in this paper research}

Methodology cross the range of factors that motivate people, it is increasingly clear that the public sector needs to rethink the offer it makes to its employees. Implicitly, the "old deal" for public service employment: relied on people wanting to work in jobs and for organisations concerned with serving the public good; (Van Fleet, D.D \& Yukl, G.A 1989)

- offered generally good pensions, benefits and job security, but limited prospects for promotion, which was 
generally slow; and provided limited flexibility in compensation and no direct link between pay and performance.

- Ploicy development

- SMEand business development

- Efficient municipal administration

- Coherent links among urban planning, infrastructure and economic development

- Services and Employment

\begin{tabular}{|c|c|c|c|c|c|}
\hline & Alternative choice & AA1 & AA2 & AA3 & AA4 \\
\hline First choice & 120 & 181 & 37 & 59 & 34 \\
\hline Second choice & 47 & 111 & 92 & 63 & 44 \\
\hline Factual value & $\mathrm{Zf}=\left(\mathrm{R}_{1 \mathrm{~m}}-\mathrm{M}_{\mathrm{R}}\right) / \mathrm{SR}_{1}$ & $\mathrm{Zf}=\left(\mathrm{R}_{2 \mathrm{~m}}-\mathrm{M}_{\mathrm{R} 3}\right) / \mathrm{SR}_{2}$ & $\mathrm{Zf}=\left(\mathrm{R}_{3 \mathrm{~m}}-\mathrm{M}_{\mathrm{R}}\right) / \mathrm{SR}_{3}$ & $\mathrm{Zf}=\left(\mathrm{R}_{4 \mathrm{~m}}-\mathrm{M}_{\mathrm{R} 5}\right) / \mathrm{SR}_{4}$ & $\mathrm{Zf}=\left(\mathrm{R}_{5 \mathrm{~m}}-\mathrm{M}_{\mathrm{R} 6}\right) / \mathrm{SR}$ \\
\hline
\end{tabular}

This article was made created by respecting all the methodological rules. The methodology of this article was based in two parts: Studying the foreign and Albanian literature, bibliographic studies, collecting data from official sources as ALR, BB Albania, MOE,CBR in Albania. (Dumi A, AJIS 2012, vol1, nr 2)

Resources and from different publications such as magazines.Practicing, which is related with the interviews with leaders and employees of the Public Administration. To collect the data for this article we made interviews, questionnaires and other researches. We created also a questionnaire, which was composed by 230 questions and 5.8\% of the employees in the central level of the public administration answered.

We are concluding in these seven key factors for success, such as:

- A dynamic local government leadership

- A coherent strategy acted upon with determination

- A healthy climate of cooperation with business

- Local government's investment initiatives to jumpstart the stagnant economy

To the question "Is the performance evaluation objective in your institution?"- 30\% answered positively, 64\% avoided the answer and $36 \%$ of them think that it is dictated from the subjectivity of the leaders. According to the questionnaire the major part of the questioned employees think that the performance evaluation takes to conflicts between the subordinate and the superiors. This is also another factor that contests rewarding according to the performance.

(Yukl, G.A) (Zaccaro, S.J, Foti, R.J \& Kenny 1999)

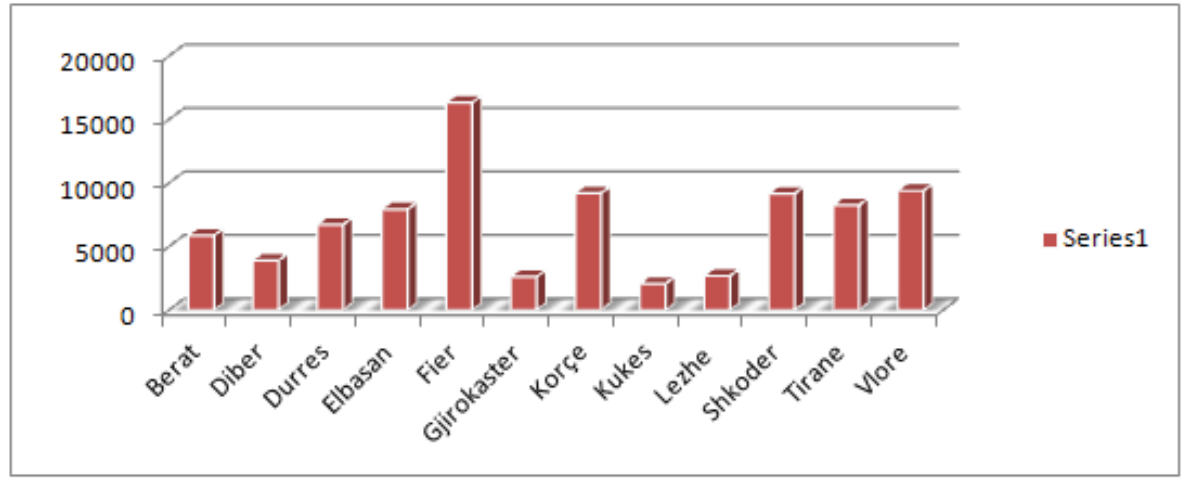

Graph 6: The regression analyze in Albanian conditions. (Dumi Alba, JESR 2012, vol2, nr 3)

- We calculate the factual value $\mathrm{Zf}$ and is compared with $\mathrm{Zk}$ that is the statistic value at a critic level.

- $Z f=\left(R_{1 m}-M_{R}\right) / S R_{1}=(30-20) / 4.8=2$ The variance is to from seven to nine $\{7,9\}$

- $\mathrm{Zfj}+\mathrm{Zff}-(\mathrm{Mr} 2-\mathrm{Mi} 1)$ is the difference of variance in this interval of $\mathrm{Zf}$ from $\{1$ to 99$\}$

- $\mathrm{Zfj}+\mathrm{Zff}-(\mathrm{Mr}$ 9-Mi1) is the difference of variance in this interval of $\mathrm{Zf} \mathrm{jr}$ from $\{11$ to 99$\}$

$\mathrm{Zf}>\mathrm{Zk} ; 2>1.76$ The variance is to from seven to nine $\{1,7-9,78\}$ This calculation shows that the hypothesis is not 
valid.In the performance evaluation the subjectivism has high levels. It is important to find other parameters for the evaluation, and this is a commitment of this article in the future. (Dumi A, AJIS 2012, vol1, nr 2)

\section{Conclusions and recommendation}

Work experience gained should be clearly relevant to a wide range of employers. Beyond that, the existence of known career paths and the prospect of promotion based on ability (rapid, where merited) would help position the public services as attractive employers. The Ministry of Economy has the responsibility for SME policy development. The Ministry of Economy's Business Promotion Department is responsible for designing, reviewing and implementing the SME policies and programmes. A key responsibility is the preparation and approval of the National SME Strategy, whose implementation the SBDA will oversee once it is created.

The first draft SME strategy was created in 1996 but due to a number of circumstances, such as the economic and financial turmoil of 1997, Kosovo crisis of 1999, etc. this was only approved by the Albanian government in February 2001.The results from this article show that the performance evaluation is a very important element in the Public Administration, and it effects the improvement of the work in the state and central bodies.

We recomanded these conclusions:

The performance evaluation conditions the emplacement and the implementation of the standards as referential points. Emplacing standards would increase the responsibility for each post in the Public Administration and will help in monitoring the performance of the institution. Lack of access to land and the on going process of fragmentation of family holdings have led to widespread poverty, prompting out migration.To meet these daunting challenges, the canton democratized its planning and management procedures.

1. Creating an enabling environment for private investment

2. Empowering citizens to pursue their own self improvement

3. promoting privatization of the housing a stock and fostering the development of micro- enterprises

4. Ensuring the sustainability of activities initiated

5. Promoting the reliability of successful initiatives.

This process allowed the canton to build consensus, prepare a development plan, allocate municipal funds equitably leverage additional resources and improve infrastructure and living conditions. The participatory municipal management improve infrastructure and living conditions. The participatory municipal management process was institutionalizes ensuring representation of women and marginalizes groups.Introducing participatory planning and community-based development processes through neighborhood development committees and street representatives working in partnership with the city.Albanian government will be reality these points:

- A dynamic local government leadership

- A coherent strategy acted upon with determination

- A healthy climate of cooperation with business

- Local government's investment initiatives to jumpstart the stagnant economy

- Creative use EU funds to implement local policy

- Efficient municipal administration

\section{References}

Dumi Alba, JESR 2012, vol2, nr 3, "The cultural leadership and job discribtion in Albania, pp239-247" Italy

Dumi Alba, MJSS 2012, vol 3, nr 3 "The influences of FDI in Albania and Macedonia" pp 251-259, Italy

Quinn, R.E. "Beyond rational management" Mastering the paradoxes and competing demands of high performance". San Francisco: Jossey-Bass, 1988.USA

Quinn, R.E. Spreitzer, G.M \& Hart, S. "Challenging the assumptions of bipolarity: interpenetration and managerial effectiveness. In S.Srivastva and R. Fry Executive continuity San Francisco, CA: Jossey-Bass, 1991.USA

Schlenker, B.R. Impression management: the self-concept, social identity and interpersonal relations.Monterey, USA: Brooks/Cole Publishing Company, 1980.

Staw, B.M \& Ross, J. Journal of Applied Psychology, 1980, 65(3), 249-260.

Stogdill, R.M. personal factors associated with leadership: A survey of the literature. Journal of psychology, 1948/, 25, 35-71.USA

Van Fleet, D.D \& Yukl, G.A. "Military leadership: an organizational behavior perspective". Greenwich, CT: JAI Press, 1986.

Vroom, V.H \& Yetton, E.W. "Leadership and decision making".Pittsburgh University Press, 1973

Wheaton, B. Assesment of fit in overidentified models with latent variables. J.s. Long 2012. Common problems/propers solutions: 
Avoiding error in quantitative research. Beverly Hills, CA: Sage, 1988.

Yukl, G.A. "A New Taxonomy for Intergrating Diverse Perspectives Managerial Behavior". Paper presented at the American Psychological Association meeting, New York, 1987.Yukl, G.A. USA"Leadership in organization" Englewood Cliffs, NJ: PrenticeHall, 1989.

Zaccaro, S.J, Foti, R.J \& Kenny, D.A. Self-monitoring and trait-based variance in leadership: An investigation of leader flexibility across multiple team situations. Journal of Applied Psychology, 1991, 76(2), 308-315. 